\title{
CAUSES OF DIFFERENTIATED DEVELOPMENT OF REGIONAL STRUCTURES IN THE SLOVAK REPUBLIC
}

\author{
Katarína Král'ová ${ }^{1}$ \\ Jana Sochul'áková ${ }^{2}$ \\ Dagmar Petrušová ${ }^{3}$
}

DOI: https://doi.org/10.31410/LIMEN.2020.133

\begin{abstract}
Our paper aims to identify and evaluate the factors determining the differentiated development of the regional structure of the Slovak Republic through analysis; directly or indirectly to show the reasons for the lag of some regions of the Slovak Republic. We will analyze the socio-economic lag of the regions in Slovakia through relevant social and economic indicators (e.g. unemployment rate, economic performance, the sectoral structure of the economy, state of infrastructure, average wages, selected demographic structures, level of innovation and others). We calculate and evaluate regional disparities using selected methods, which should point us to the fact that the differences between developed and lagging regions have already reached such proportions that regional polarization and regional disparities are entirely appropriate for this situation.
\end{abstract}

Keywords: Region, Regional structure, Regional disparities, Regular polarization.

\section{INTRODUCTION}

$\mathrm{R}$ egional differences and insufficient regional development have long been a problem not only of the Slovak economy. We can state that regional differences are the result of the uneven distribution of available resources within the economy and can lead to even greater and deepening problems between individual regions of the economy. Let's ask ourselves what a region is, how to correctly define a region in terms of comparing regional development or measuring the performance of regions. The regions represent complex and richly structured units. The term region in general represents a territorial-administrative or political-administrative unit with a precisely defined competence of administrative bodies in the territory, while it has certain resources (internal or external) forming the preconditions for its development (Habánik, 2014). Some regions of the Slovak Republic are more developed, others less so. Each region is different, it is characterized differently, it has different conditions for its growth and development and this is the reason why certain differences arise and exist between individual regions of the Slovak Republic. In the Slovak Republic, regional disparities began to grow after 1989, due to social and economic changes. Subsequent economic growth and development in the Slovak Republic gradually contributed to the emphasis on differences between regions and districts of Slovakia, which led to the emergence of regional polarization. These significant differences between the regions, which have gradually formed in the Slovak

Alexander Dubček University in Trenčín, Faculty of Social and Economic Relations, Študentská 3, 91150 Trenčín, Slovakia

2 Alexander Dubček University in Trenčín, Faculty of Social and Economic Relations, Študentská 3, 91150 Trenčín, Slovakia

3 Alexander Dubček University in Trenčín, Faculty of Social and Economic Relations, Študentská 3, 91150 Trenčín, Slovakia 
economy, are very large and have many accompanying negative consequences, and the regions themselves often fail to address this effectively. The main reason for the emergence of these differences, not only in the past but also today, is the existence of different possibilities and capabilities of regions to adapt and respond flexibly to new economic and social conditions. (Korec, Polonyová, 2011, p.165) Švecová and Rajčáková (2014) also point to the fact that the democratization process, which we embarked on in 1989 and was accompanied by a transformation in the political, economic, social, cultural and environmental fields, significantly affects the socio-spatial situation in society after 1989. (p. 259) Tvrdon et al. (2007) is based on the assumption that the main causes of regional disparities can be considered the specificity of natural potential, settlement structure, location attractiveness, demographic structure, transport infrastructure, territorial accessibility or economic specialization of regions, and last but not least the influence of territorial - administrative arrangement. In view of the current nature of the growing trends of regional disparities in Slovakia, regional disparities are generally considered an undesirable situation in the process of regional development, which negatively affects their social and economic development, quality of life and regionally polarizes society. (Gajdoš, 2005, p. 116)

However, we must also point out that these regional differences, which can be a source of social tension on the one hand, or can threaten the economic stability of the region, can also be an incentive for the development of the region development disparities. Thus, disparities are generally understood as inequalities or differences. In our paper, we will understand them as differences in the degree of socio-economic development of individual regions of the Slovak Republic. Our analysis focuses on 8 regions according to the NUTS 3 categorization, the observed development represents 10 time periods. An indicator or a group of indicators is a means for us to evaluate a regional or spatial structure and its changes. Indicators for measuring regional development and disparities should meet certain requirements:

- should reflect changes in the level of socio-economic development,

- should be detectable,

- should be optimal for use in analysis.

Therefore, when selecting indicators, we selected indicators that reflect both economic and social aspects of development or lagging regions, which we were able to obtain from official statistics. In order to achieve a more objective assessment of regional structure and development, we chose the unemployment indicator, the average nominal monthly wage indicator, the regional gross domestic product per capita in EUR, the motorway network in $\mathrm{km}$, the number of high school students in the regions, crime in the region.

\section{EVALUATION OF REGIONAL DIFFERENCES IN THE CONDITIONS OF THE SR}

Regional disparities can be caused by several economic and non-economic factors. The causes of regional disparities are diverse and thus limit the opportunities for development and growth of regions. We consider the area of household income to be one of the basic factors that significantly affects the emergence of disparities. In table no. 1 we have recorded the development of average nominal wages of employees in individual regions of the Slovak Republic. In the observed period, in all regions of the Slovak Republic, average nominal wages increased by an average of 50\% over the last 10 years. The largest increase was in the Trenčín region and the smallest, if we do not take into account the Bratislava region, was in the Košice region. 
Based on the sigma convergence indicator, which will be shown in figure 1, we can evaluate the convergence of regions. We speak of convergence if the value of the sigma indicator decreases during the observed period. Based on our analysis, which we performed over the period, it is clear that the value of the sigma convergence indicator calculated from the average nominal wages of employees in individual regions of the Slovak Republic decreased from 0.0655 to 0.0592 , which is a $9.61 \%$ decrease.

Table 1. Average nominal monthly salary of an employee in EUR

\begin{tabular}{|l|c|c|c|c|c|c|c|c|c|c|c|}
\hline & $\mathbf{2 0 1 0}$ & $\mathbf{2 0 1 1}$ & $\mathbf{2 0 1 2}$ & $\mathbf{2 0 1 3}$ & $\mathbf{2 0 1 4}$ & $\mathbf{2 0 1 5}$ & $\mathbf{2 0 1 6}$ & $\mathbf{2 0 1 7}$ & $\mathbf{2 0 1 8}$ & $\mathbf{2 0 1 9}$ & index \\
\hline $\begin{array}{l}\text { Region of } \\
\text { Bratislava }\end{array}$ & 1160 & 1124 & 1184 & 1205 & 1294 & 1322 & 1377 & 1426 & 1532 & 1646 & $\mathbf{1 , 4 1}$ \\
\hline Region of Trnava & 787 & 815 & 848 & 860 & 900 & 938 & 982 & 1050 & 1114 & 1204 & $\mathbf{1 , 5 2}$ \\
\hline $\begin{array}{l}\text { Region of } \\
\text { Trenčín }\end{array}$ & 732 & 774 & 798 & 821 & 872 & 909 & 960 & 1020 & 1094 & 1186 & $\mathbf{1 , 6 2}$ \\
\hline Region of Nitra & 707 & 753 & 776 & 789 & 835 & 860 & 915 & 959 & 1034 & 1126 & $\mathbf{1 , 5 9}$ \\
\hline Region of Žilina & 759 & 801 & 816 & 839 & 877 & 920 & 960 & 1018 & 1088 & 1180 & $\mathbf{1 , 5 5}$ \\
\hline $\begin{array}{l}\text { Region of Banská } \\
\text { Bystrica }\end{array}$ & 702 & 756 & 772 & 798 & 845 & 866 & 908 & 940 & 1023 & 1113 & $\mathbf{1 , 5 8}$ \\
\hline Region of Prešov & 659 & 697 & 718 & 736 & 771 & 800 & 833 & 875 & 928 & 1025 & $\mathbf{1 , 5 5}$ \\
\hline Region of Košice & 792 & 848 & 853 & 883 & 925 & 947 & 986 & 1025 & 1110 & 1179 & $\mathbf{1 , 4 8}$ \\
\hline
\end{tabular}

Source: Statistical Office of the Slovak Republic

This means that, in terms of the average nominal wage indicator, there is a gradual convergence of regions. Nevertheless, the lowest value during the whole period is reached by the Banská Bystrica and Prešov regions.

Figure 1. Sigma convergence

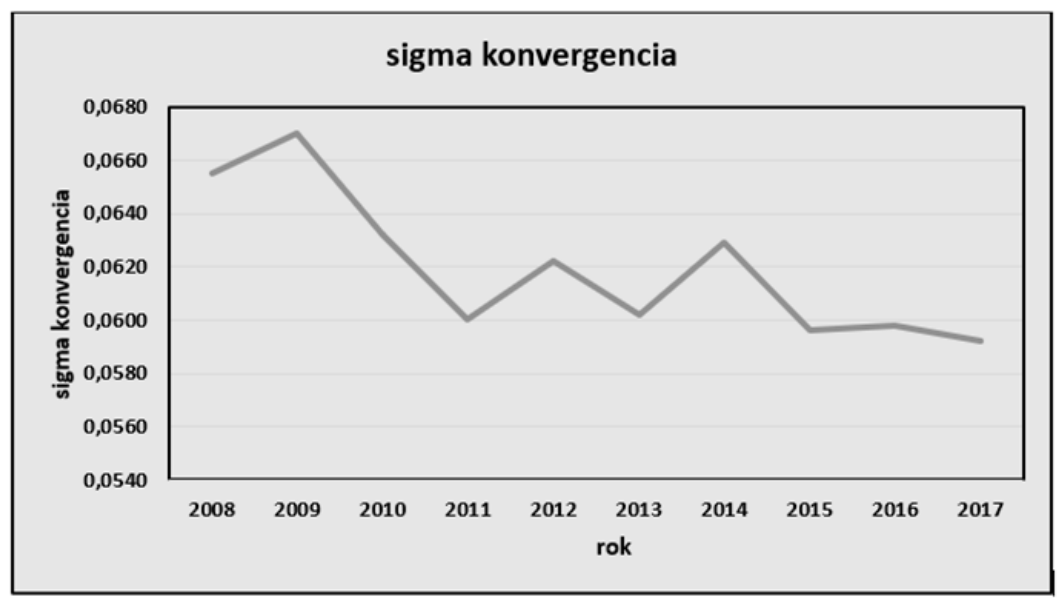

Source: own processing

The indicator regional gross domestic product per capita expresses to us, although not directly, what is the economic activity of the population in the region, what is the employment in the region, unemployment, or household income. In the period under review, gross regional product per capita grew in individual regions. The largest increase was recorded in the Prešov region, but nevertheless, the achieved gross regional product per capita reaches only $26.7 \%$ of the level shown by the most developed region of the Slovak Republic, namely Bratislava. Among other facts, this is also due to the fact that the Prešov region has long had the lowest average nominal wage rate among the regions and also the highest unemployment rate, which is reflected in the amount of total gross regional product. The Prešov region is one of the regions with the highest population. 
Table 2. Regional gross domestic product per capita in EUR

\begin{tabular}{|l|c|c|c|c|c|c|c|c|c|c|c|}
\hline \multicolumn{10}{|c|}{ Regional gross domestic product per capita in EUR } \\
\hline & index & $\mathbf{\%}$ & $\mathbf{2 0 1 8}$ & $\mathbf{2 0 1 7}$ & $\mathbf{2 0 1 6}$ & $\mathbf{2 0 1 5}$ & $\mathbf{2 0 1 4}$ & $\mathbf{2 0 1 3}$ & $\mathbf{2 0 1 2}$ & $\mathbf{2 0 1 1}$ & $\mathbf{2 0 1 0}$ \\
\hline $\begin{array}{l}\text { Region of } \\
\text { Bratislava }\end{array}$ & 1,24892 & 24,98 & 38836 & 37514 & 36657 & 36158 & 34461 & 34544 & 32862 & 32794 & 31096 \\
\hline $\begin{array}{l}\text { Region of } \\
\text { Trnava }\end{array}$ & 1,2924 & 29,24 & 17917 & 16702 & 16191 & 15668 & 15778 & 15073 & 15187 & 14940 & 13864 \\
\hline $\begin{array}{l}\text { Region of } \\
\text { Trenč́n }\end{array}$ & 1,25928 & 25,92 & 13742 & 12512 & 12411 & 12553 & 12015 & 11700 & 12003 & 11706 & 10912 \\
\hline Region of Nitra & 1,36974 & 36,97 & 13769 & 13293 & 12572 & 12200 & 12029 & 11805 & 12189 & 11135 & 10052 \\
\hline Region of Žilina & 1,26882 & 26,88 & 14079 & 13306 & 12912 & 12891 & 12275 & 11718 & 11714 & 11770 & 11096 \\
\hline $\begin{array}{l}\text { Region of } \\
\text { Banská Bystrica }\end{array}$ & 1,31184 & 31,18 & 12064 & 11292 & 10753 & 10578 & 9912 & 9847 & 9666 & 9586 & 9196 \\
\hline Region of Prešov & 1,47194 & 47,19 & 10389 & 9308 & 9036 & 8807 & 8360 & 8017 & 8076 & 7360 & 7058 \\
\hline Region of Košice & 1,33942 & 33,94 & 13353 & 12896 & 11730 & 11891 & 11112 & 10732 & 10650 & 10191 & 9969 \\
\hline
\end{tabular}

Source: Statistical Office of the Slovak Republic

As Table 3 shows, it has $19.5 \%$ more inhabitants than the Bratislava Region. This fact also ultimately affects the amount of regional gross product per capita in the region.

Table 3. Status of permanent population in the region

\begin{tabular}{|c|c|c|c|c|c|c|c|c|c|c|}
\hline \multicolumn{11}{|c|}{ Population density } \\
\hline & 2010 & 2011 & 2012 & 2013 & 2014 & 2015 & 2016 & 2017 & 2018 & 2019 \\
\hline $\begin{array}{l}\text { Region of } \\
\text { Bratislava }\end{array}$ & 625834 & 603234 & 609609,5 & 615531 & 621773,5 & 629227,5 & 637590 & 646365 & 655218 & 664595 \\
\hline $\begin{array}{l}\text { Region of } \\
\text { Trnava }\end{array}$ & 562391 & 554765 & 556043 & 557092,5 & 558142,5 & 559187 & 560426,5 & 561764 & 562981,5 & 564254 \\
\hline $\begin{array}{l}\text { Region of } \\
\text { Trenčín }\end{array}$ & 599018 & 594320 & 593672,5 & 592776,5 & 591813,5 & 590584 & 589375,5 & 588090 & 586623 & 585225,5 \\
\hline $\begin{array}{l}\text { Region of } \\
\text { Nitra } \\
\end{array}$ & 705193 & 689937,5 & 688982 & 687531 & 685792 & 683724,5 & 681653 & 679735,5 & 677682 & 6754489 \\
\hline $\begin{array}{l}\text { Region of } \\
\text { Žilina }\end{array}$ & 698009 & 688948 & 689861 & 690270,5 & 690434,5 & 690441,5 & 690606 & 690900,5 & 691195,5 & 691438,5 \\
\hline $\begin{array}{l}\text { Region of } \\
\text { Banská } \\
\text { Bystrica }\end{array}$ & 652800 & 660559,5 & 659309 & 657651,5 & 656086 & 654191,5 & 652266,5 & 650648,5 & 648831 & 646575 \\
\hline $\begin{array}{l}\text { Region of } \\
\text { Prešov }\end{array}$ & 808532 & 814706 & 816594 & 818149 & 819446,5 & 820337 & 821503,5 & 823068 & 824424 & 825633 \\
\hline $\begin{array}{l}\text { Region of } \\
\text { Košice }\end{array}$ & 779247 & 791914 & 793508 & 794390,5 & 795160,5 & 796107,5 & 797376,5 & 798660 & 799815,5 & 800937 \\
\hline
\end{tabular}

Source: Statistical Office of the Slovak Republic

Also, in terms of the level of registered unemployment, the Prešov region is the worst together with the Kossice region. On the positive side, compared to previous years, the unemployment rate in all regions showed a significant decline and in 2019 reached a historically lowest level. The lowest unemployment rates have long been in the Bratislava and Trnava regions.

Table 4. Registered unemployment rate in \%

\begin{tabular}{|l|c|c|c|c|c|c|c|c|c|c|c|}
\hline \multicolumn{9}{|c|}{ Registered unemployment rate (in \%) } \\
\hline & index & $\mathbf{2 0 1 9}$ & $\mathbf{2 0 1 8}$ & $\mathbf{2 0 1 7}$ & $\mathbf{2 0 1 6}$ & $\mathbf{2 0 1 5}$ & $\mathbf{2 0 1 4}$ & $\mathbf{2 0 1 3}$ & $\mathbf{2 0 1 2}$ & $\mathbf{2 0 1 1}$ & $\mathbf{2 0 1 0}$ \\
\hline $\begin{array}{l}\text { Region of } \\
\text { Bratislava }\end{array}$ & $\mathbf{0 , 6 1 1 2}$ & 2,83 & 2,62 & 3,05 & 4,51 & 5,34 & 6,13 & 6,17 & 5,72 & 5,41 & 4,63 \\
\hline Region of Trnava & $\mathbf{0 , 3 2 1 9}$ & 2,63 & 2,31 & 2,6 & 4,41 & 6,71 & 8,03 & 9,16 & 9,43 & 8,88 & 8,17 \\
\hline $\begin{array}{l}\text { Region of } \\
\text { Trenčín }\end{array}$ & $\mathbf{0 , 3 3 6 5}$ & 3,2 & 2,93 & 3,53 & 5,85 & 7,71 & 9,56 & 10,74 & 10,89 & 9,95 & 9,51 \\
\hline Region of Nitra & $\mathbf{0 , 2 4 9 1}$ & 2,93 & 3,12 & 4,05 & 6,96 & 9,71 & 11,21 & 12,52 & 14,08 & 13,27 & 11,76 \\
\hline Region of Žilina & $\mathbf{0 , 3 6 4 6}$ & 3,96 & 4,04 & 4,7 & 6,92 & 8,86 & 10,91 & 12,51 & 12,79 & 11,91 & 10,86 \\
\hline $\begin{array}{l}\text { Region of Banská } \\
\text { Bystrica }\end{array}$ & $\mathbf{0 , 3 5 4 7}$ & 6,69 & 7,03 & 8,67 & 12,8 & 14,94 & 17,22 & 18,26 & 20,81 & 19,83 & 18,86 \\
\hline
\end{tabular}




\begin{tabular}{|l|l|l|l|l|l|l|l|l|l|l|l|}
\hline Region of Prešov & $\mathbf{0 , 4 6 1 4}$ & 8,19 & 8,61 & 9,68 & 13,91 & 15,5 & 17,45 & 19,35 & 20,66 & 18,95 & 17,75 \\
\hline Region of Košice & $\mathbf{0 , 4 5 1 1}$ & 7,57 & 8,17 & 9,94 & 12,76 & 14,39 & 15,92 & 17,23 & 19,58 & 18,76 & 16,78 \\
\hline
\end{tabular}

Source: Statistical Office of the Slovak Republic

A very important part of the evaluation of the development of the region is also the level of the educational process. The results of the education system in the region and the degree of lagging behind in the region are strongly linked. Given the high rate of intergenerational reproduction of educational outcomes as well as the educational structure of long-term unemployed jobseekers, it can be argued that the educational outcomes of pupils in the regions largely predict the future unemployment rate in the region. From the point of view of the forecast of the development of a specific area, it can be said that the overall results of children's education are an important indicator determining the unemployment rate in the region in the future.

Table 5. Number of secondary vocational school students

\begin{tabular}{|l|c|c|c|c|c|c|c|c|c|c|c|c|c|}
\hline \multicolumn{10}{|c|}{ inumber of secondary vocational school students } \\
\hline & index & $\mathbf{\%}$ & $\begin{array}{l}\text { abs. } \\
\text { val. }\end{array}$ & $\mathbf{2 0 1 9}$ & $\mathbf{2 0 1 8}$ & $\mathbf{2 0 1 7}$ & $\mathbf{2 0 1 6}$ & $\mathbf{2 0 1 5}$ & $\mathbf{2 0 1 4}$ & $\mathbf{2 0 1 3}$ & $\mathbf{2 0 1 2}$ & $\mathbf{2 0 1 1}$ & $\mathbf{2 0 1 0}$ \\
\hline $\begin{array}{l}\text { Region of } \\
\text { Bratislava }\end{array}$ & 0,781 & $-21,91$ & -2994 & 10670 & 10336 & 10336 & 10383 & 10426 & 10658 & 10847 & 11537 & 12437 & 13664 \\
\hline $\begin{array}{l}\text { Region of } \\
\text { Trnava }\end{array}$ & 0,675 & $-32,51$ & -4793 & 9952 & 10239 & 10630 & 10957 & 11378 & 11748 & 12263 & 12923 & 13871 & 14745 \\
\hline $\begin{array}{l}\text { Region of } \\
\text { Trenčín }\end{array}$ & 0,565 & $-43,5$ & -8796 & 11423 & 11945 & 12516 & 13196 & 14049 & 14857 & 15754 & 17264 & 19035 & 20219 \\
\hline $\begin{array}{l}\text { Region of } \\
\text { Nitra }\end{array}$ & 0,644 & $-35,62$ & -7818 & 14130 & 14708 & 15243 & 16202 & 16661 & 16996 & 17812 & 18891 & 20568 & 21948 \\
\hline $\begin{array}{l}\text { Region of } \\
\text { Žilina }\end{array}$ & 0,635 & $-36,47$ & -9005 & 15689 & 16336 & 17012 & 17729 & 18784 & 19456 & 20436 & 21721 & 23152 & 24694 \\
\hline $\begin{array}{l}\text { Region of } \\
\text { Banská } \\
\text { Bystrica }\end{array}$ & 0,69 & $-30,97$ & -5551 & 12374 & 12983 & 13337 & 13567 & 13900 & 14388 & 15007 & 15760 & 16803 & 17925 \\
\hline $\begin{array}{l}\text { Region of } \\
\text { Prešov }\end{array}$ & 0,635 & $-36,54$ & -9210 & 15995 & 16650 & 17531 & 17931 & 18618 & 19439 & 20324 & 21914 & 23334 & 25205 \\
\hline $\begin{array}{l}\text { Region of } \\
\text { Košice }\end{array}$ & 0,676 & $-32,36$ & -7124 & 14889 & 15161 & 15922 & 16943 & 17457 & 17995 & 18211 & 19141 & 20179 & 22013 \\
\hline
\end{tabular}

Source: Statistical Office of the Slovak Republic

Figure 2. Map of the least developed regions of the Slovak Republic

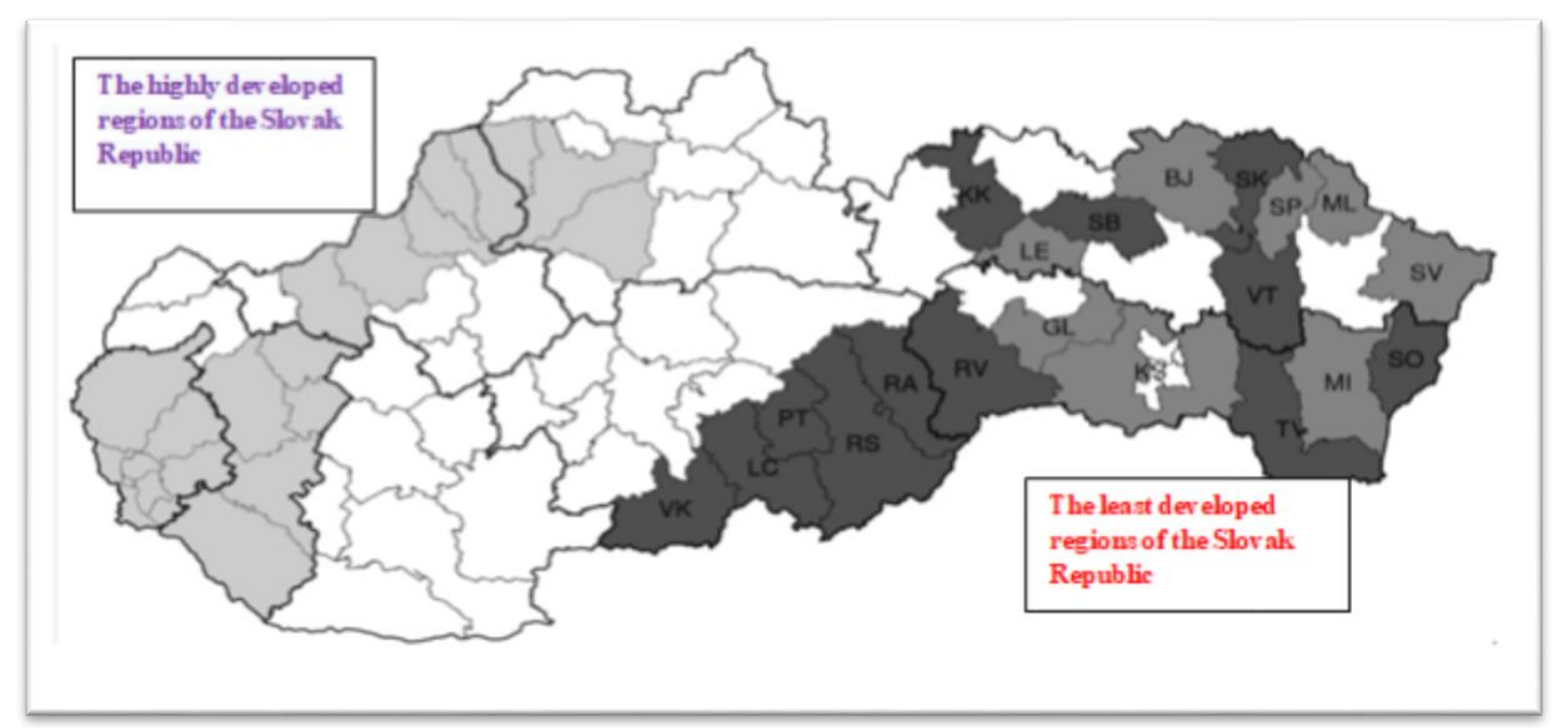

In addition to economic, regional disparities also have social and political consequences. Because disparities prevent the achievement of sufficient economic growth within the region, 
production is reduced and available resources are not used efficiently. Differences in living standards cause dissatisfaction and outrage in the population of the regions, higher crime rates and social exclusion in regions with high unemployment, which also has political consequences. Increasing criminality also brings with it an increase in the costs associated with its suppression or prevention.

Disparities cause problems not only in lagging regions, but also in developed regions. In fastgrowing regions, economic costs are rising due to growing demand for infrastructure and public goods. Disparities also cause inflationary pressures. These arise in regions with intense competition in the field of skilled labor, which occurs mainly in times of expansion and results in wage growth. High wages cause an increase in demand for apartments and this leads to an increase in apartment prices. Regional disparities can then also increase because high housing costs become a barrier to, for example, population (labor) immigration.

The causes of regional disparities are therefore diverse. This may be the different equipment of regions with production factors (labor, capital, technology), insufficient or irrational use of production factors, differences in economic structure of regions, social capital, relatively low mobility of labor and capital, differences in demand for regional products, different consumption habits, different ability to create innovations, different geographical, natural and historical conditions, different geographical size of regions, demographic characteristics and differences in educational level, chance or historical event, different political and institutional factors, traditions, differences in culture, etc. And these facts caused in the conditions of the Slovak Republic a differentiated development of regional structures of the Slovak Republic, as we can see on the map in Figure 2.

\section{CONCLUSION}

In conclusion, we can state that regional disparities are basically reflected in the uneven development of regions. This is a fact that causes inequalities in social, economic and living conditions of the inhabitants of individual regions of the Slovak Republic. Deepening and nonresolution of regional disparities can lead to the formation of marginal regions, with all the signs of lagging behind in the economic and social area and to the formation of the so-called regions of poverty. Already today, there are $27.7 \%$ of districts in Slovakia, which are referred to as the least developed regions of the so-called regions of poverty. These regions occupy one fifth of the area of the territory of the Slovak Republic, which is really a large share of the territory, which lags significantly behind other areas of the Slovak Republic. 12 districts, which are referred to as poverty regions, are located in the Prešov region, six are in the Košice region and five in the Banská Bystrica region. The lag of these regions was also confirmed by the analysis of selected economic indicators.

\section{REFERENCES}

Baštová, M., Hubáčková, V., Frantál, B. (2011) Interregional differences in the Czech Republic, 2000-2008. Moravian Geographical Reports, Brno: Novpress, roč. 19. č. 1, s. 2-16

Gajdoš, P. (2005) Diferenciácia regionálneho rozvoja Slovenska a jej sociálno-priestorové súvislosti a dopady. In: New members - new challenges for the European regional development policy. Košice, EF 
Goschin, Z., Constantin, D., Roman, M., Ileanu, B. (2008). The Current State and Dynamics of Regional Disparities in Romania. In Romanian Journal of Regional Science, Vol. 1, No. 2, s. 80-105.

Habánik, J. a kol. (2014) Regionálna ekonomika a regionálny rozvoj. TnUAD Trenčín, 245 s. Hučka, M., Kern, J., Kutscherauerer, A., Malinovský, J., Sucháček, J., Tománek, P. (2008) Vznik regionálních disparit, jejich pojetí, charakteristika a klasifikace (studie). Ekonomická fakulta Vysoké školy báņské - Technické Univerzity Ostrava. http://disparity.vsb.cz/vysledky/03_studie_du2.pdf

Korec, P., Polonyová, E. (2011) Zaostávajúce regióny Slovenska - pokus o identifikáciu a poukázanie na príčiny. In: ACTA GEOGRAPHICA UNIVERSITATIS COMENIANAE, Vol. 55, 2011, No. 2, pp. 165-190

Matlovič, R., Matlovičová, K. (2011) Regionálne disparity a ich riešenie na Slovensku v rozličných kontextoch In: Folia geographica. Roč. LIII, č. 18, PU Prešov, s. 8-87

Michaeli, E., Matlovič, R., Ištok, Klamár, R., Hofierka, J., Mintálová, T., Mitríková, J. (2010). Regionálny rozvoj pre geografov. Prešov: Prešovská univerzita v Prešove, 717 s. Švecová, A., Rajčáková, E. (2014) Regionálne disparity v sociálno-ekonomickej úrovni regiónov Slovenska v rokoch 2001-2013. In: Regionálne dimenzie Slovenska. Univerzita Komenského v Bratislave.

Tvrdoň, J., Kmecová, Z. (2007): Dimenzia hospodárska - typológia regiónov.: Regionálna diferenciácia, regionálny rozvoj v Slovenskej republike v kontexte integračných dosahov. Bratislava: Sociologický ústav SAV, s. 67-81.

Výrostková, E.: Regionálna ekonomika a rozvoj, Bratislava: Iura Edition, 2010, 352 s.

http://datacube.statistics.sk/ 